DOI https://doi.org/10.18551/rjoas.2018-08.36

\title{
FACTORS AFFECTING BRAND LOYALTY: A CONSUMER SURVEY AT STARBUCKS COFFEE CAFE IN SETIABUDI BUILDING, SOUTH JAKARTA
}

\author{
Winarti C.E. \\ Faculty of Economics and Business, ABFII Perbanas, Jakarta, Indonesia \\ E-mail: endah@perbanas.id
}

\begin{abstract}
This research aims to analyze the influence of Brand Image and Brand on Brand Loyalty at Starbucks Coffee Cafe (Setiabudi Building, South Jakarta). The method used is the Survey method with the use of the questionnaire/questionnaires. Analysis Tool that is used Multiple Linear Regression. Research results show that Brand Loyalty at Starbucks Coffee Cafe influenced by Brand Image with negative results and Brand with positive results.
\end{abstract}

\section{KEY WORDS}

Brand image, brand, brand loyalty, cafe.

In the last few years in various areas of business growth continues to increase, especially business Cafe. Many explored various brand Cafe, for example Upnormal, Lawson, and Strabuck as a response to increasing community lifestyle that requires the hanging around for both socialization and business. It caused the increasingly tight competition. The companies have various strategies to win the competition. One of the strategy is to improve the quality of the product and the quality of service in the best possible way to their customers. The strategy is done so that the company can create a brand image and Brand Trust is good in the end will have an impact on Brand Loyalty

The company should build a strong brand image on a sustainable basis to maintain its market share because anyone can easily create a variety of products with almost the same quality. Brand Image is important for the survival of the company and has become the responsibility of the company to continue to manage, notice, maintain and improve the image of the good (Sugiharti, 2012).

So also with Starbucks Corporation to have a brand image and Brand Trust that strong, Starbucks Corporation has successfully create their brand as a brand that is recognized in the world. Based on the stages of the registered, Starbucks received various awards in various categories among others is the first stage of the Top Brand For Teens Index in 2018, the fifth stage of the World's Most Admired Companies by 2014, and the second stage of Social Brands Top 100 2012. For more details can be seen In Table 1, 2, 3 below.

In view of the above phenomenon indicates that the success of Starbucks built by maintaining Brand Loyalty continuously and maintain the quality of the extraordinary in terms of products and services in each cafénya. He has been able to seize it for many years so that with the image of the good and strong, with easy he gain confidence brand from its consumers. If a brand is able to meet the consumer expectations and provide quality guarantee on every usage, and the company has a good reputation, that the consumer will be more confident with the choice and consumers will have a strong confidence toward brand (Edris, 2009).

To get a strong confidence from consumers, then formed by Brand Loyalty. Brand Loyalty is a condition where consumers have a positive attitude toward the brand, has a commitment to the brand, and have a tendency to purchase in future (Tjahyadi, 2006).

The results of research and Nopiska Rizan (2011) stated that the brand image and brand trust in the same significant effect toward brand loyalty. While the results of research done by Tjahjaningsih and Yuliani (2009) that brand image does not have the direct effect of brand loyalty.

The purpose of this research is to know the influence of Brand Image and Brand Trust toward the Brand Loyalty Starbucks Coffee Cafe, Setiabudi Building, South Jakarta. 
Table 1 - Top Brand for Teens Index 2018

\begin{tabular}{|l|l|l|}
\hline \multicolumn{2}{|c|}{ CAFE/ Place Hanging Around } & TOP \\
\hline Registered & TBI & TOP \\
\hline The international Starbucks chain & $18.5 \%$ & TOP \\
\hline Lawson & $18.2 \%$ & TOP \\
\hline Upnormal Cafe & $11.6 \%$ & \\
\hline Circle of K & $6.6 \%$ & \\
\hline Indomaret Point & $6.2 \%$ & \\
\hline
\end{tabular}

Source: www.topbrand-award.com

Table 2 - The world's Most Admired Companies of the year 2014

\begin{tabular}{|c|c|c|c|}
\hline & Name & The Logo & Last Ranking \\
\hline 1. & Apple & Apple & 1 \\
\hline 2. & Amazon.com & amazon.com & 3 \\
\hline 3. & Google & & 2 \\
\hline 4. & Berkshire Hathaway & Brzksuer Fatraway mo. & 8 \\
\hline 5. & Starbucks & & 5 \\
\hline 6. & Coca Cola & & 4 \\
\hline 7. & FedEx & & 10 \\
\hline 8. & Southwest Airlines & & 7 \\
\hline 9. & General Electric & & 11 \\
\hline 10. & American Express & & 13 \\
\hline 11. & Costco & & 23 \\
\hline 12. & Nike & & 18 \\
\hline 13. & BMW & & 14 \\
\hline 14. & $P \& G$ & & 15 \\
\hline 15. & IBM & 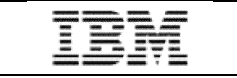 & 6 \\
\hline 16. & Nordstrom & NORDSTROM & 16 \\
\hline 17. & Singapore Airlines & 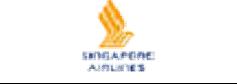 & 31 \\
\hline 18. & Johnson \& Johnson & Gohmon affohnon & 24 \\
\hline 19. & Whole Food Market & $\begin{array}{l}\text { WHÖLE } \\
\text { FOODS }\end{array}$ & 19 \\
\hline
\end{tabular}

Source: www.rankingthebrands.com 
Table 3 - Social Brands Top 100, 2012

\begin{tabular}{|c|c|c|}
\hline & Name & The Logo \\
\hline 1. & Innocent Drinks & (1) innocent \\
\hline 2. & Starbucks & Q \\
\hline 3. & Giffgaff & giffgaff \\
\hline 4. & Cancer Research UK & cancor reseaschum \\
\hline 5. & British Red Cross & odcross \\
\hline 6. & ARKive & Afкive \\
\hline 7. & Asos.com & 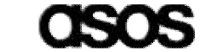 \\
\hline 8. & Confectionery maker Cadburysliding & Oasbury \\
\hline 9. & The Met Office & Met oftce \\
\hline 10. & The Ellen DeGeneres Show & - \\
\hline 11. & HTC & hT \\
\hline 12. & Guiness World Records & \\
\hline 13. & Lurpak & LURPAK \\
\hline 14. & Red Bull & RedBull \\
\hline 15. & Xbox & $8 \mathrm{XBOX}$ \\
\hline 16. & Manchester United Football Club & \\
\hline 17. & WWF & $\underset{w W F}{4}$ \\
\hline 18. & DoSomething.org & DOO \\
\hline 19. & Cravendale & \\
\hline 20. & Help for Heroes & $\begin{array}{l}\text { DHELP for } \\
\text { HEROES }\end{array}$ \\
\hline
\end{tabular}

Source: www.rankingthebrands.com

The study of the library and the development of the hypothesis. Brand Image is an important thing for the consumer. It is because at the time of the consumers remember a registered then will realize positive or negative impacts of a brand. According to the opinion of Shimp (2003) that brand image is something that appears in the minds of consumers when they remember a brand. Then According To Tjiptono (2015:49) "brand image is the description of the association and consumer confidence to certain brand".

Brand Trust according to Prasaranphanich (2007: 23) is when consumers believe a company, they prefer to purchase repeatedly and share personal information is valuable for the company. While according to(Lau \& Lee, 1999, p. 344) in (Rizan, Saidani, \& Sari 2012). 
Customer trust in the brand (brand trust) is defined as a customer desire to rely on a brand with the risks faced by the expectations of the brand will cause a positive result.

According to Ariestonandri (2006: 63) it was basically nationality brand loyalty as an indication of how loyal customers using the brand that offered. While according to Riana (2008:187) customer loyalty can be based on actual purchase behavior product that is associated with the proportion of purchase. Based from the view and brand loyalty is defined as a customer desire to do re-purchase.

The results of research done by Tjahjaningsih and Yuliani (2009) that brand image does not have the direct effect of brand loyalty.

Sibagariang Research \& Nursanti (2010) "The Influence of Brand Image and Brand Trust toward the brand loyalty on PT Bank Sinarmas" the result shows that the variables brand image and brand trust influential simultaneously against the brand loyalty of PT Bank Sinarmas.

Research \& Nopiska Rizan (2011) the influence of brand image and trust the brand against brand loyalty: Lux Customer Survey in Liquid Carrefour MT Haryono the result shows that the variables brand image and brand trust has positive and significant impact on the brand loyalty.

Research Rizan, Saidani, \& Sari (2012) "the influence of brand image and brand trust toward the brand Loyalty Bottle Teh Sosro", shows that the brand image and brand trust has a positive and significant effect of brand loyalty.

Laroche research (2012) explore whether brand community based on social media (special type of registered online community) have positive effects on the elements of the main community and the practice of the creation of the value in Indonesia. The results of the study showed that the brand belief have full mediation role in converting the practice of making the value to the brand loyalty.

Saaed (2013) test the influence of brand image brand loyalty and moderate the role of customer satisfaction in it. The research results show the impact of marketing communication and consumer knowledge about brand loyalty. The organization must pay special attention to the formation of brand image, achieve customer satisfaction and then through this they also become successful in reaching the brand loyalty.

Bastian (2014) Analysis of the influence of brand image (Brand Image) and Trust Brand (Brand Trust) to brand loyalty (Brand Loyalty) ADES PT. Ades Alfindo Putra Faithful the result shows that the variables brand image and brand trust affect brand loyalty.

Lee (2015) examine about the effect of using the Blackberry users to customer satisfaction, trust and brand loyalty. Findings from this research assert that the simplicity and interactivity is two significant determinants of mobile phone functionality and simplicity of the interface is important prerequisites for positive interactivity and usability experience.) We also show that the utility is the defining brand loyalty, summoning the influence of not directly through the mediator of customer satisfaction and trust.

Hypothesis development:

- H1: Brand image affect brand loyalty;

- H2: Brand trust affected brand loyalty.

\section{METHODS OF RESEARCH}

Researchers obtain data directly with the spread of the questionnaire to consumers Starbucks Coffee Cafe, Setiabudi Building, South Jakarta who had been selected as respondents.

The population of this research is the consumers of Starbucks Coffee Cafe, Setiabudi Building, South Jakarta with samples of 60 respondents.

Validity test is used to test the validity or accuracy of the measuring cup, to verify whether the information as expected.

From the table of variables Brand Image, the variables Brand Trust, and variables Brand Loyalty can be explained that all statements contained in the variables stated valid. 
Reliability test is intended to show the nature of the appliance to measure whether enough accurate, stable or consistent in measuring what would be measured. Brand Image, Brand Trust, And Brand Loyalty results of Cronbach Alpha coefficient greater than $60 \%$ (0.60) means that all statements contained in each variable does not exist that are not reliable and can be used for further analysis.

$$
Y=\alpha+\beta 1(B R A N D I M A G E)+\beta 2(B R A N D T R U S T)+s
$$

Where: $\mathrm{Y}=$ Brand Loyalty; $\mathrm{B} 1=$ Regression Coefficient Brand Image; $\mathrm{B} 2=$ Regression Coefficient Brand Trust; X1 = Variables Brand Image; X2 = Variables Brand Trust; $\mathrm{E}=$ Standard error.

Test statistics $t$ used to know the influence of each free variable namely brand image and Brand trust against the variables bound namely brand loyalty. With this t test can be known which of the free variable has the influence of most of the variables are bound.

The $F$ test is used to test whether the model used to explain the influence of the independent variables (X1: Brand Image and X2: Brand Trust) to the dependent variables (Y: Brand Loyalty) accepted or not.

Basically the determination coefficient (R2) is used to measure how far the ability model (brand image and Brand Trust) in explaining the variation of the dependent variables (Brand Loyalty). The determination coefficient value is between zero (0) and one (1). The value of $\mathrm{R} 2$ that bigger means the ability of independent variables in explaining the dependent variations, the better. The value of nearly one means independent variables provide almost all the information needed to predict the variation of the dependent variables.

\section{RESULTS AND DISCUSSION}

Multiple Regression Analysis. In this research used double regression with the aim to know is whether or not the influence of the free variables of the variables are bound together.

Table 4 - Multiple Regression Measurement between Brand Image and Brand Trust Toward the Brand Loyalty

\begin{tabular}{|c|c|c|c|c|c|c|}
\hline \multirow{2}{*}{\multicolumn{2}{|c|}{ Model }} & \multicolumn{2}{|c|}{ Unstandardized Coefficients } & \multirow{2}{*}{$\begin{array}{c}\text { Standardized Coefficients } \\
\text { Beta }\end{array}$} & \multirow[t]{2}{*}{$\mathrm{t}$} & \multirow[t]{2}{*}{ Sig. } \\
\hline & & $\mathrm{B}$ & STD. Error & & & \\
\hline \multirow{3}{*}{1} & (Constant) & -2.100 & .825 & & -2.546 & .014 \\
\hline & brandimage & -.176 & .067 & -.393 & -2.605 & .012 \\
\hline & brandtrust & & .2021 .812 & 1.355 & 8.985 &, 000 \\
\hline
\end{tabular}

From the results when written in the form of common regression is as follows:

$$
Y=-2.100-0.176(B R A N D I M A G E)+1.812(B R A N D T R U S T)+\varepsilon
$$

Free variable regression coefficient $\mathrm{X} 1$ amounting - 0,176 with the level of any contributed 0.012 smaller than from the alpha level 0.05 , which has the meaning of free variable brand image influence significantly to the bound variable brand loyalty. The value of variable regression coefficient of negative brand image shows that the influence of the brand image of brand loyalty is not the direction, means when brand image low, then will increase brand loyalty or when the brand image high then will reduce the brand loyalty;

Free variable regression coefficient X2 amounting 1.812 with any 0,000 level smaller than from the alpha level 0.05 , which has the meaning of free variable brand trust significant effect against the variables bound brand loyalty. The value of variable regression coefficient brand trust that positive indicates that the influence of brand trust toward the brand loyalty clockwise means when brand image low, then will reduce the brand loyalty or when the brand image high then will increase brand loyalty. 
From both the free variables (X1= brand image, $\mathrm{X} 2=$ brand trust) that have the greatest effects/dominant against brand loyalty is brand trust with the value of Beta 1.812.

$F$ Test results. $F$ tests the test is used to test the model used to explain the influence of ( $\mathrm{X} 1=$ brand image and $\mathrm{X} 2=$ brand trust) against the variables bound ( $\mathrm{Y}=$ brand loyalty). The Test Results Table $F$ is served under this

Table 5 - F Test Results

\begin{tabular}{|l|c|c|c|c|c|c|}
\hline \multicolumn{7}{|c|}{ AANOVA } \\
\hline \multicolumn{2}{|c|}{ Model } & Sum of Squares & df (disk free) & Mean Square & F & Sig. \\
\hline \multirow{3}{*}{1} & Regression & 743.816 & 2 & 371.908 & 514.939 &, $000^{\text {b }}$ \\
\cline { 2 - 7 } & Residual & 41.168 & 57 & .722 & & \\
\cline { 2 - 7 } & Total & 784.983 & 59 & & \\
\hline \multicolumn{7}{|c|}{ a. Dependent Variables: brandloyalty } \\
\hline
\end{tabular}

Based on the results of the ANOVA test or $F$ test on the following table obtained $F$ count of 514.939 using the level of confidence $95 \%$, alpha $(\alpha)=5$ percent degree of freedom (degree of freedom) quantifiers of k-1 or 3-1 = 2 and the degree of freedom both operate $(n-k)$ or $60-3=57$ ( $n$ is the amount of data and $k$ is the number of independent variables and dependent service), then obtained the results of $F$ the table of 2.18. Can be known $F$ count of 514.939 greater than $F$ the table of 2.18. This shows that the Ho was rejected and $\mathrm{Ha}$ accepted. This means that the model used to explain the influence of Brand Image and Brand Trust toward the Brand Loyalty accepted.

The determination coefficient $\mathrm{R}^{2}$ is used to measure the ability of the models in the describe the variation of the dependent variables, the value of the determination coefficient as follows:

Table 6 - The results of the determination Coefficient

The Model Summary ${ }^{\mathrm{b}}$

\begin{tabular}{|l|l|l|l|l|}
\hline The Model & R & R Square & It said the R Square & Std. The error of the Estimate \\
\hline 1 & A.973 & .948 & .946 & They have \\
\hline
\end{tabular}

A. Predictors: (Constant), brandtrust, brandimage

B. Dependent Variables: brandloyalty

Source: Data processing result SPSS 20.

Based on the following table known $\mathrm{R}$ of 0,973 near 1 means that the brand image and brand trust strong effect toward brand loyalty, on it said the R Square of 0,948 or $94,8 \%$ factors that affect brand loyalty can be explained by factors brand image and brand trust, while at 5.2 percent is another factor that is not examined.

In this discussion will be analyzed the influence of each variable namely Brand Image and Brand Trust toward the brand loyalty.

The results of this research shows that the Brand Loyalty Starbucks Coffee Cafe, Setiabudi Building, South Jakarta influenced by the brand image and the results of his negative. This means that the higher the brand image to encourage people to reduce the Brand Loyalty. This is less fair because should Brand Image is high will encourage customers to have a Brand Loyalty that high. This can occur is possible because of the use of respondents less many. The results of this research is slightly different with the results of research \& Nopiska Rizan (2011) shows that the brand image variables and trust the brand has positive and significant impact on the brand loyalty while the results of this research Brand Image have pengrus but negative. This research is the exact opposite of conjoint with the results of research done by Tjahjaningsih and Yuliani (2009) that brand image does not have the direct effect of brand loyalty.

Brand Loyalty Starbucks Coffee Cafe, Setiabudi Building, South Jakarta influenced by Brand Trust and positive result. This means that the higher the Brand Trust encouraging people to increase brand loyalty. This is fair because consumers who have brand trust that the higher then will be encouraged to have a brand loyalty that stronger. The results of this 
research in line with the results of research Bastian (2014) that (brand image Brand Image) and Trust Brand (Brand Trust) affect brand loyalty (Brand Loyalty).

\section{CONCLUSION}

The results of research on the influence of brand image and brand trust toward the brand loyalty Starbucks Coffee Cafe, Setiabudi Building, South Jakarta can be summarized as follows:

- Brand image negative effect toward brand loyalty Starbucks Coffee Cafe, Setiabudi Building, South Jakarta;

- Brand trust positive effect toward brand loyalty Starbucks Coffee Cafe, Setiabudi Building, South Jakarta.

\section{RECOMMENDATIONS}

In this research the author provide recommendations that might be useful for Starbucks Coffee Cafe or for further research that is as follows.

To Starbucks:

- Related to the brand image recommended more increase in the case of a solution for customer expectations, this is due to the variable brand image on the dimensions;

- Related to the brand trust recommended more confidence to customers in terms of providing services more than expected consumers and does not disappoint in terms of quality and service, this variables especially on the dimensions of benevolence has lowest value compared to other indicators.

For Further Research:

- It is expected that can examine with more variables in order to obtain a better result;

- It is recommended to use the number of samples more so that the result more optimal.

\section{REFERENCES}

1. Ariestonandri, Prima. (2006). Marketing Research for Beginner Practical Guide Marketing Research for the beginner. Yogyakarta: ANDI.

2. Bastian, Danny Alexander. (2014). Analysis of the influence of brand image (Brand Image) and Trust Brand (Brand Trust) to brand loyalty (Brand Loyalty) ADES PT. Ades Alfindo Putra faithful. The Journal of Marketing Management Petra, Vol.2, No.1.

3. Laroche, M. et al (2012). The effects of social media based brand communities on brand community markers, value creation practices, brand trust and brand loyalty. Computers in Human Behavior, 28 (5), 1755-1767.

4. Lee, D, Moon, J., Kim, Y. J., \& Mun, Y. Y. (2015). Antecedents and consequences of mobile phone awarded: Linking simplicity and interactivity to satisfaction, trust, and brand loyalty. Information \& Management, 52 (3), 295-304.

5. Philip Kotler and Kevin Lane Keller. 2009. Marketing Management Volume 1, Thirteenth Edition, Translation Bob Sabran, MM. Jakarta: Erlangga Publisher.

6. Prasaranphanich, Pattarawan. (2007). Does Trust Matter to · Develop Customer Loyalty in Online Business. International Journal of Marketing Studies.

7. Riana, Gede. (2008). The influence of Trust In a Brand Of Brand Loyalty In Consumers Drinking Water Aqua in Denpasar city. Economic Studies bulletin, Vol.13, No.2.

8. Rizan, Mohamad \& Nopiska, Yuli. (2011). The influence of the Image and trust the brand against brand loyalty Survey Customers Lux Liquid in Carrefour MT. Haryono. The Journal Econosains, Vol.9, No.1.

9. Rizan, Mohammad, Basra Saidani, and Yusiyana Sari. (2012). The influence of Brand Image and Brand Trust toward the Brand Loyalty Tea Bottle Teh Sosro. Research journal Science Management Indonesia, Vol.3, No.1. 
10. Saeed, R., Lodhi, R. N., Mehmood, A., Ishfaque, U, Dustgeer, F. Sami, A.,... Ahmad, M. (2013). Effect of brand image on brand loyalty and role of customer satisfaction in it. World Applied Sciences Journal, 26 (10), 1364-1370.

11. Sibagariang, Christina Havilah \& Nursanty, Tinjung Desy. (2010). The influence of Brand Image and Brand Trust toward the Brand Loyalty on PT Bank Sinarmas. Journal The Winners, Vol.11, No.2.

12. Sugiharti. (2012). Build a positive brand image in order to create customer loyalty and satisfaction.JBMA, Vol.1, No.1.

13. Shimp, A. (2003). Advertising Promotion Additional aspects of the Integrated Communication. Jakarta: Erlangga Publisher.

14. Tjahyadi, Rully Arlan. (2007). Brand Trust in the context of brand loyalty: The role of brand characteristics, Company characteristics and characteristics of the relationship Pelanggan-Merek. The Journal of Management, Vol.6, No.1.

15. Tjahjaningsih, Endang \& Yuliani, Maurine. (2009). Analysis of product quality and brand image in affect the purchase decision and the impact on brand loyalty Hp Nokia. The Journal Examine Management. ISSN: 1693-9727.

16. Tjiptono, F. (2015). Brand Management and Strategy. Yogyakarta: Andi.

17. Electronic source: http://www.starbucks.co.id

18. Electronic source: http://www.starbucks.com

19. Electronic source: http://www.rankingthebrands.com

20. Electronic source: http://www. id.m.wikipedia.org/wiki/starbucks

21. Electronic source: http://www.catatansejarah.com/sejarah-berdiri-perusahaan-minumanstarbucks

22. Electronic source: http://www.topbrand-award.com 